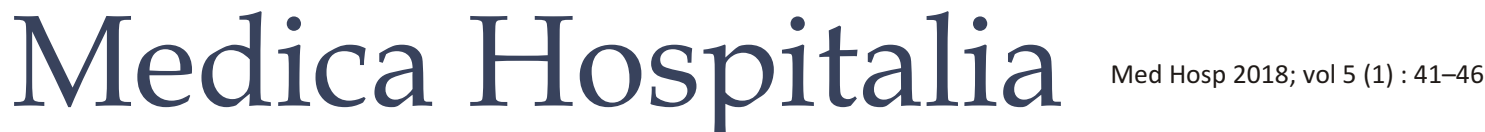

Original Article

\section{Perbedaan Nilai Total Thrombocyt Count (TC), Platelet Distribution Width (PDW) dan Mean Platelet Volume (MPV) pada Penderita Chronic Renal Failure (CRF) Tanpa Hemodialisa dan dengan Hemodialisa}

\author{
Indrawan Guruh $\mathrm{Adi}^{1}$, Purwanto Adhipireno ${ }^{2}$
}

1PPDS Bagian Patologi Klinik, Fakultas Kedokteran,Universitas Diponegoro, Semarang
Bagian Patologi Klinik, Fakultas Kedokteran, Universitas Diponegoro, Semarang

\begin{abstract}
Abstrak
Latar belakang : Pasien dengan penyakit ginjal kronis memiliki resiko kehilangan darah yang disebabkan disfungsi platelet.Penyebab lain adalah proses terapi hemodialisis. Tujuan penelitian ini, membuktikan adanya perbedaan Total Thrombocyt Count (TC), Platelet Distribution Width (PDW) dan Mean Platelet Volume (MPV) antara penderita CRF tanpa dan dengan hemodialisa, sehingga dapat mengoptimalkan parameter pemeriksaan hematologi otomatis yang sering dilakukan dengan memanfaatkan indek trombosit sebagai parameter prognostik tingkat keparahan penyakit.

Metode : Sampel darah EDTA 72 penderita CRF berusia 8-80 tahun, yang dirawat di RSUP Dr. Kariadi, bulan November 2015 - April 2016, diperiksa complete blood count (CBC) menggunakan hematologi analyzer metode flowcitometri Cell-Dyn Sapphire. Hasil pemeriksaan masing-masing kelompok di analisis menggunakan Uji Statistik One Way Anova.

Hasil : Hasil penelitian pada 2 kelompok diagnosis didapatkan rerata nilai TC kelompok HD 177,93 $\pm 79,52$, kelompok Non HD $244,11 \pm 111,98$. Rerata PDW kelompok HD 14,78 $\pm 2,72$, kelompok Non HD 14,24 $\pm 2,48$ dan rerata MPV kelompok HD $7,90 \pm 1,50$, kelompok Non HD 8,43 $\pm 2,05$. Perbedaan nilai TC yang signifikan CRF non HD dengan HD $(p<0,001)$ Nilai TC kelompok CRF Non HD lebih tinggi secara bermakna dibandingkan kelompok CRF dengan HD. Nilai TC menurun sesuai tingkat keparahan CRF. Hasil penelitian ini menunjukkan perbedaan nilai TC secara bermakna antara kelompok pasien CRF non $\mathrm{HD}$ da dengan $\mathrm{HD}(p<0,05)$.

Simpulan : Nilai TC berbeda secara bermakna antara kelompok pasien CRF Non HD dengan pasien CRF dengan HD. TC menurun sesuai dengan tingkat keparahan CRF dan dapat digunakan sebagai petanda tingkat keparahan CRF.
\end{abstract}

Kata kunci : Chronic Renal Failure, Hemodialisa, Total Count Thrombocyt, Mean Platelet Volume, Platelet Distribution Width

\author{
Difference of total value Thrombocyte \\ Count (tc), Platelet Distribution \\ Width (PDW) and Mean Platelet Volume (MPV) \\ in patients Chronic Renal Failure (crf) \\ without hemodialisa and with hemodialisa
}

\section{Abstract}

Background : Patients with chronic kidney disease have an increased risk of blood loss caused by platelet dysfunction. Other causes, especially hemodialysis. The purpose of this study to prove the difference Total Thrombocyt Count (TC), Platelet Distribution Width (PDW) and Mean platelet volume (MPV) patients with CRF without and with hemodialysis, which is expected to optimize the parameters inspection automated hematology which is often done by utilizing platelets index as a prognostic parameters of disease severity.

Methods : Blood samples EDTA 72 CRF patients aged 8-80 years, in various stages of being treated at Dr. Kariadi Central Hospital in November 2015 - April 2016, the examination complete blood count $(\mathrm{CBC})$ using a hematology analyzer flowcitometri method Cell-Dyn Sapphire. The results of the examination of each group was analyzed using One Way Anova Test Statistics.

Results : The study of two groups of diagnoses obtained a mean value of TC HD group $177.93 \pm 79.52$, Non-HD group $244.11 \pm$ 111.98. The mean PDW HD group $14.78 \pm 2.72$. Groups Non HD $14.24 \pm 2.48$ and the average MPV HD group $7.90 \pm 1.50,8.43 \pm \mathrm{HD}$ Non groups of 2.05. TC significant value differences between patient CRF without and with HD $(p<0.001)$ Value without HD TC CRF group was significantly higher than the group of CRF with HD. TC value decreases as the severity of CRF. The results showed differences in the value of TC significantly between groups of patients CRF without and with $\mathrm{HD}(p<0.05)$. 
Conclusion : TC values significantly different between groups of patients with CRF Non-HD with a group of CRF patients with HD. TC decreased according to the severity of CRF. TC can be used as a marker for the severity of CRF.

Keywords : Chronic Renal Failure, Hemodialysis, Total Count Thrombocyt, Mean platelet volume, Platelet Distribution Width

\section{PENDAHULUAN}

Gagal ginjal terjadi ketika ginjal tidak mampu berfungsi secara normal. Ada dua jenis gagal ginjal yaitu akut dan kronis. Gagal ginjal akut memiliki onset mendadak, dan berpotensi reversibel. Sedangkan gagal ginjal kronis berlangsung perlahan-lahan selama setidaknya tiga bulan dan dapat menyebabkan gagal ginjal permanen. Penyakit ginjal kronis biasanya disebabkan oleh penyakit jangka panjang, seperti hipertensi dan diabetes, yang secara perlahan merusak ginjal dan mengurangi fungsi ginjal dari waktu ke waktu. ${ }^{1}$ Penyakit Gagal Ginjal Kronik (CRF) merupakan suatu proses patofisiologi dengan etiologi yang beragam, mengakibatkan penurunan fungsi ginjal yang progresif, dan pada umumnya berakhir dengan keadaan klinis yang ditandai dengan penurunan fungsi ginjal yang irreversible, pada suatu derajat yang memerlukan terapi pengganti ginjal yang tetap, berupa dialisis atau transplantasi ginjal. Akibat fungsi renal menurun, produk akhir metabolisme protein (yang normalnya dieksresikan melalui urine) tertimbun dalam darah. Terjadi uremia dan mempengaruhi setiap sistem tubuh, semakin banyak timbunan produk sampah, maka gejala akan semakin berarti. Banyak permasalahan yang muncul pada ginjal sebagai akibat dari penurunan glomerolus, yang menyebabkan penurunan clearens substansi darah yang seharusnya dibersihkan oleh ginjal. ${ }^{1,2}$

Thrombopoetin merupakan hormon glikoprotein yang diproduksi khususnya didalam hati dan ginjal, yang berfungsi meregulasi produksi trombosit oleh sumsum tulang dan diferensiasi megakariosit, sehingga sel sumsum tulang akan membentuk trombosit yang banyak. Sebagian kecil thrombopoetin diproduksi oleh otak dan testes. Thrombopoetin disintesis dan secara cepat dilepaskan seperti layaknya erytropoiesis. ${ }^{3}$ Pasien dengan penyakit ginjal kronis memiliki resiko kehilangan darah yang disebabkan oleh disfungsi platelet. Penyebab lain kehilangan darah pada pasien gagal ginjal kronis ini adalah dari proses terapi dialisis, terutama hemodialisis. Hemodialisa adalah terapi yang bertujuan untuk menggantikan fungsi ginjal yang rusak. Gagal ginjal tahap akhir, apapun etiologinya, memerlukan pengobatan khusus yang disebut pengobatan atau terapi pengganti (TP) yaitu hemodialisa. ${ }^{4,5}$ Disfungsi platelet menjadi faktor utama terjadinya perdarahan pada pasien dengan penyakit ginjal kronik. Disfungsi platelet dapat terjadi karena kelainan intrinsik dari platelet serta gangguan interaksi platelet-pembuluh darah. Disfungsi platelet dapat disebabkan karena uremic toxin pada pasien penyakit ginjal tahap lanjut. Respon normal pada perdarahan yaitu aktivasi platelet, recruitment, adhesi dan agregasi menjadi tidak efektif pada pasien dengan penyakit ginjal kronik. Terapi dialisis dapat mengurangi disfungsi dan kelainan dari platelet, namun tidak menghilangkan resiko dari perdarahan. ${ }^{3}$

Parameter hasil pemeriksaan darah rutin yang kita lakukan belum dimanfaatkan secara optimal dalam memperkirakan progresivitas suatu penyakit, khususnya pada kasus CRF, seperti parameter indeks trombosit yaitu Total Thrombocyt Count (TC), Platelet Distribution Width (PDW), Mean Platelet Volume (MPV) dan Platelet - Large Corpuscular Ratio (P-LCR). Index trombosit seperti TC, MPV, PDW dan P-LCR telah diteliti sebagai petanda fungsi dan aktifitas platelet yang dapat diukur menggunakan analyser hematologi. MPV adalah parameter yang mengukur ukuran atau volume rata-rata trombosit dan dapat digunakan sebagai prediktor independen adanya suatu proses perdarahan serta dapat menggambarkan aktifitas sumsum tulang. Korelasi antara jumlah trombosit dan index trombosit dengan perdarahan dan keparahan penyakit berpotensi dapat memprediksi outcome suatu penyakit. PDW adalah rentang atau lebar distribusi trombosit yang menunjukkan variasi ukuran trombosit yang beredar dalam darah perifer, trombosit muda berukuran lebih besar, sedangkan trombosit tua mempunyai ukuran yang lebih kecil seiring dengan makin bertambahnya usia trombosit. PDW dapat digunakan untuk membedakan antara trombositosis reaktif dan trombositosis yang disebabkan oleh kelainan mieloproliferatif, immaturitas juga untuk membedakan trombositopenia akibat kerusakan trombosit atau akibat penurunan produksi.

\section{METODE}

\section{Sampel Penelitian}

Penelitian ini melibatkan 72 sampel darah EDTA penderita Chronic renal failure 8-80 tahun, dari berbagai stage dan etiologi, yang dirawat di RSUP Dr. Kariadi Semarang antara bulan November 2015 - April 2016 dan dilakukan pemeriksaan complete blood count (CBC) metode flowcitometri Cell-Dyn Sapphire. Kriteria eksklusi 
penelitian ini adalahpasien keganasan, kelainan hematologi lainnya, infeksi atau penyakit lain yang mengganggu fungsi sumsum tulang dan atau trombosit serta mengkonsumsi obat-obat yang mengganggu fungsi sumsum tulang dan atau trombosit.

Penelitian ini dilakukan selama 6 bulan, Ethical clearance diperoleh dari institusi Komite Etik Penelitian Kedokteran dan Kesehatan, Fakultas Kedokteran Universitas Diponegoro Semarang, dengan no. 479/EC/FK-RSDK/2016.

\section{Analisis Data}

Hasil penghitungan nilai TC, PDW dan MPV pada berbagai kelompok penderita Chronic renal failure dilakukan analisis menggunakan program komputer, perhitungan deskriptif (distribusi, frekuensi, rerata) kemudian dilakukan uji normalitas data Independent t-test dan Mann Whitney test didapatkan hasil distribusi data normal, kemudian dilakukan Uji Beda One Way Anova. Nilai $p$ dianggap bermakna jika $p<0,05$.

\section{HASIL}

Penelitian terhadap 72 pasien laki-laki maupun perempuan penderita Chronic renal failure yang dirawat di RSUP Dr. Kariadi Semarang, didapatkan 72 pasien penderita chronic renal failure yang terdiri dari 36 pasien (50\%) menderita CRF stage I-IV karena berbagai etiologi yang tidak mendapatkan terapi Hemodialisa dan sebanyak 36 pasien (50\%) terdiagnosis CRF stage V (ESRD) yang mendapat terapi Hemodialisa. Diagnosis tersebut ditegakkan menurut kriteria NKF-KDOQI, 2002 berdasarkan kriteria klinis dan kriteria laboratorium.

Tabel 1 menunjukkan bahwa dari jumlah total pasien yang diteliti, usia rata-rata pasien CRF tanpa Hemodialisa adalah 51,75 tahun $( \pm 16,674), 2$ diantaranya berusia 8 dan 9 tahun. Sedangkan usia rata-rata pasien CRF dengan Hemodialisa adalah 48,58 tahun $( \pm 12,998)$, 1 diantaranya berusia 79 tahun.

Tabel 2 menunjukkan bahwa dari jumlah total pasien yang diteliti, pasien laki-laki sebanyak 37 pasien (16 penderita CRF tanpa HD dan 21 penderita CRF dengan HD), pasien perempuan sebanyak 35 pasien (20 penderita CRF tanpa HD dan 15 penderita CRF dengan HD).

Tabel 3 menunjukkan gambaran nilai TC, PDW dan MPV pada kedua kelompok penderita Chronic Renal Failure. Perbedaan nilai rerata indeks trombosit yang signifikan didapatkan pada nilai TC antara CRF tanpa hemodialisa dan CRF dengan hemodialisa $(p<0,001)$.

Hasil penelitian pada 2 kelompok diagnosis didapatkan rerata nilai TC $177,93 \pm 79,52$ pada kelompok HD vs $244,11 \pm 111,98$ pada kelompok Non HD. Rerata nilai PDW 14,78 $\pm 2,72$ pada kelompok HD vs 14,24 $\pm 2,48$ pada pasien Non HD. Rerata nilai MPV 7,90 $\pm 1,50$ pada kelompok HD vs 8,43 $\pm 2,05$ pada kelompok Non HD. Hal ini menunjukkan penurunan nilai TC seiring tingkat keparahan penyakit. Berdasarkan analisis statistik antara CRF non HD dengan CRF dengan HD didapatkan perbedaan nilai TC yang signifikan antara CRF non HD dengan CRF dengan HD $(p<0,05)$ (Tabel4).

TABEL 1

Karakteristik Umur

Kelompok

Umur

Mean \pm SD

Median (Min - Maks)

Hemodialisa

Non Hemodialisa

$48,58 \pm 12,998$

$50(27-79)$

Total

$51,75 \pm 16,674$

$52,5(8-79)$

$50,17 \pm 14,929$

$51,5(8-79)$

\section{TABBEL 2}

Karakteristik Jenis Kelamin

Jenis Kelamin

Hemodialisa

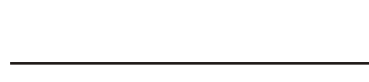

Laki-laki

Perempuan

n $\%$

$21 \quad 58,3$

$15 \quad 41,7$

Kelompok Non Hemodialisa

n $\%$

$16 \quad 44,4$

20

55,6
Total

\% $\quad$ n $\quad \%$

$44,4 \quad 37$

35

51,4

48,6 


\section{TABEL 3}

Hasil analisis uji One Way Anova, TC, PDW dan MPV pada penderita Chronic renal failure tanpa hemodialisa dan Chronic renal failure dengan Hemodialisa

\begin{tabular}{|c|c|c|c|c|c|}
\hline \multirow[t]{2}{*}{ Variabel } & \multirow[t]{2}{*}{ Mean \pm SD } & \multirow{2}{*}{$\begin{array}{c}\text { Median } \\
\text { (Min - Maks) }\end{array}$} & \multicolumn{2}{|c|}{ Shapiro-Wilk } & \multirow[t]{2}{*}{ Keterangan } \\
\hline & & & $\boldsymbol{p}$ & tranf & \\
\hline \multicolumn{6}{|l|}{$\mathrm{Hb}$} \\
\hline Hemodialisa & $8,78 \pm 1,32$ & $8,45(6,7-12,3))$ & 0,092 & - & Normal \\
\hline Non Hemodialisa & $9,55 \pm 2,30$ & $8,9(5,2-16,2)$ & 0,199 & - & Normal \\
\hline \multicolumn{6}{|l|}{ TC } \\
\hline Hemodialisa & $177,93 \pm 79,52$ & $160(10,7-407)$ & 0,181 & 0,000 & Tidak Normal \\
\hline Non Hemodialisa & $244,11 \pm 111,98$ & $212(104-629)$ & 0,004 & 0,823 & Normal \\
\hline \multicolumn{6}{|l|}{ PDW } \\
\hline Hemodialisa & $14,78 \pm 2,72$ & $15,55(9,4-20,1)$ & 0,074 & 0,010 & Tidak Normal \\
\hline Non Hemodialisa & $14,24 \pm 2,48$ & $15,4(9,2-18,4)$ & 0,000 & 0,000 & Tidak Normal \\
\hline \multicolumn{6}{|l|}{ MPV } \\
\hline Hemodialisa & $7,90 \pm 1,50$ & $7,81(5,17-10,8)$ & 0,625 & 0,612 & Normal \\
\hline Non Hemodialisa & $8,43 \pm 2,05$ & $8,34(5,65-16,7)$ & 0,000 & 0,025 & Tidak Normal \\
\hline
\end{tabular}

TABEL 4

Keterangan Hasil Uji Beda Hb, TC, PDW dan MPV berdasarkan Kelompok HD dan Non HD

Variabel

$\begin{array}{ll}\mathrm{Hb} & 0,091^{¥} \\ \mathrm{TC} & 0,008^{\mp} \\ \mathrm{PDW} & 0,290^{\mp} \\ \mathrm{MPV} & 0,350^{\mp}\end{array}$

\section{Keterangan}

$¥$ Independent t-test

f Mann Whitney test

\section{DISKUSI}

Trombosit berperan pada proses hemostasis, penyembuhan luka dan infeksi. Trombositopenia merupakan manifestasi umum yang sering ditemukan pada pasien-pasien dengan kondisi kritis yang terjadi akibat penurunan pembentukan, penggunaan atau kerusakan trombosit berlebihan. ${ }^{1}$

Thrombopoietin, suatu ligan reseptor faktor pertumbuhan megakariosit, saat ini dikenal sebagai regulator humoral utama produksi megakariosit dan trombosit. Thrombopoietin mempengaruhi pertumbuhan megakariosit mulai dari sel induk sampai produksi trombosit. $^{3}$

Pada stadium paling dini penyakit ginjal kronik, terjadi kehilangan daya cadang ginjal (renal reserve), pada keadaan LFG (laju filtrasi glomerulus) masih normal atau meningkat. Kemudian secara perlahan akan terjadi penurunan fungsi nefron yang progresif, yang ditandai dengan peningkatan kadar urea dan kreatinin serum. Pada LFG sebesar $60 \%$, pasien masih belum merasakan keluhan tapi sudah terjadi peningkatan kadar urea dan kreatinin serum. Pada LFG 30\%, mulai terjadi keluhan seperti nokturia, badan lemah, mual, nafsu makan kurang, dan penurunan berat badan. Pada LFG $<30 \%$ pasien memperlihatkan gejala dan tanda uremia yang nyata, seperti anemia, peningkatan tekanan darah, mual dan sebagainya. Sedangkan pada LFG 15\% akan terjadi gejala dan komplikasi yang lebih serius antara lain dialisis atau transplantasi ginjal.

Ketika gangguan ini berkepanjangan dan memasuki fase kronis, sekresi eritropoietin dan 

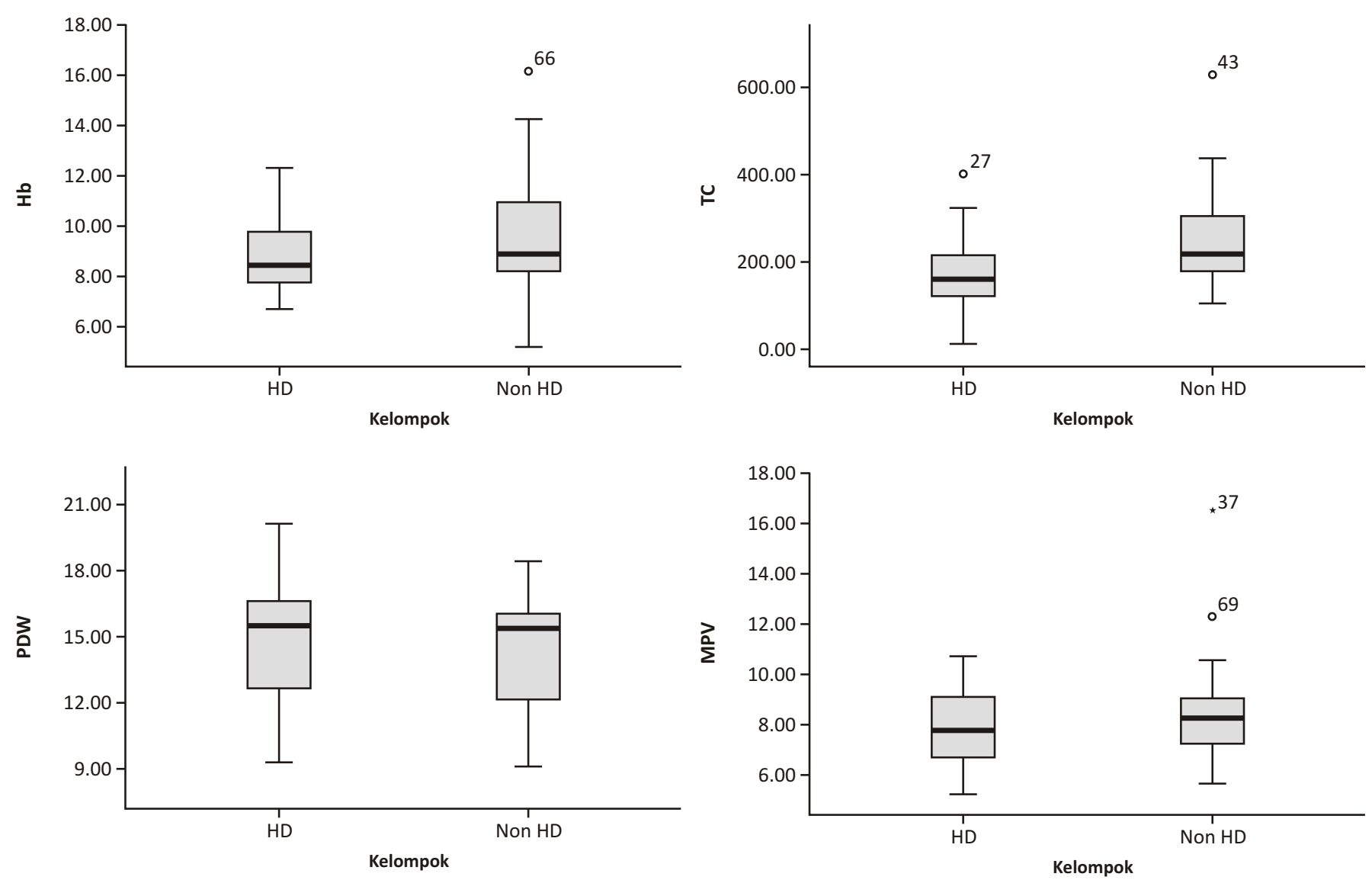

Gambar 1. Perbandingan Hb,TC,PDW dan MPV pada Kelompok Penderita CRF tanpa HD dan Penderita CRF dengan HD

thrombopoietin oleh organ ini menurun dan metabolisme zat beracun terakumulasi dan menyebabkan perubahan hematologi yang meliputi penurunan HCT, MCV, RBC dan jumlah trombosit. Pada uremia dilaporkan terjadi gangguan pada fungsi trombosit. Produksi prostasiklin dalam pembuluh darah akan meningkat, dan kadar ureum berlebih dalam darah akan menjadi vasodilator potensial dan antagonis agregasi trombosit. $2,6,7$

Hasil penelitian menunjukkan perbedaan nilai TC yang bermakna antara kelompok pasien CRF tanpa HD dengan pasien $\mathrm{CRF}$ dengan $\mathrm{HD}(p<0,05)$.

Telah diamati bahwa jumlah trombosit menurun (Tabel-1) pada pasien gagal ginjal kronis. $(p<0,0001$, yang signifikan). Erythropoietin mempotensiasi efek megakaryocyte colony stimulating factor, acetylhydrolase (PAF-AH) dan paraoxonase (PON1). Pada penyakit ginjal kronis, gangguan sekresi erythropoietin menyebabkan penurunan jumlah trombosit. Deteksi reseptor untuk erythropoietin di megakaryocytes dimengerti, karena tingkat erythropoietin dapat mempengaruhi tingkat trombosit dan karena homologi yang luas antara erythropoietin dan thrombopoietin, erythropoietin bertindak sebagai regulator humoral utama dari massa trombosit. Pada pasien dengan penyakit ginjal kronis yang diobati dengan erythropoietin (EPO), terjadi peningkatan kecil dalam jumlah trombosit, rata-rata sekitar 30.000 per mikroliter. Penurunan jumlah trombosit pada pasien dengan penyakit ginjal kronis menyebabkan waktu perdarahan berkepanjangan.

Penelitian ini sesuai dengan penelitian dan teori yang ada sebelumnya oleh Suresh, et al dalam penelitiannya mengungkapkan bahwaterjadi perubahan hematologi pada penderita $\mathrm{CRF}$ yaitu penurunan $\mathrm{Hb}$ dan $\mathrm{TC}^{2}$

Penelitian ini masih memiliki kelemahan karena tidak membahas indeks trombosit terhadap berbagai tingkatan CRF lainnya sebagai pembanding serta tidak mengikutsertakan hasil pemeriksaan konfirmasi manual sediaan apus darah tepi sebagai variabel penelitian, Penelitian ini bersifat cross sectional tanpa mengikuti perkembangan penyakit masing-masing subyek penelitian, sehingga tidak dapat ditentukan ada tidaknya perbedaan nilai indeks trombosit antara saat masuk Rumah Sakit dengan perkembangan selanjutnya sesuai tingkat keparahan penyakit atau kondisi pasien pulang, sehingga masih perlu dilakukan penelitian lebih lanjut. 


\section{SIMPULAN}

Perbedaan signifikan nilai TC didapatkan antara kedua kelompok penderita CRF sesuai tingkat keparahan dan derajat penyakit. Nilai TC pada pasien CRF dengan hemodialisa lebih rendah dibandingkan dengan pasien CRF tanpa hemodialisa. Rendahnya jumlah trombosit, dapat digunakan sebagai salah satu faktor predictor outcome suatu penyakit.

\section{DAFTAR PUSTAKA}

1. Frances K Widmann, Tinjauan Klinis Atas Hasil Pemeriksaan Laboratorium, EGC, ed.9. 2000.

2. Suresh, et al, Hematological Changes in Chronic Renal Failure, International Journal of Scientific and Research Publications, Volume 2, Issue 9, September 2012, ISSN 2250-3153, www.ijsrp.org

3. Harrison P. Platelet Function Analysis. Elsevier.2005; 19: 111-23
4. Jackson SP. The growing complexity of platelet aggregation.2007; 109:5087-95. Available from: http:/ / bloodjurnal.hematologylibrary.org/content /109/1205087.full

5. Lubis AJ, 2006. Dukungan soal pada pasien gagal ginjal terminal yang melakukan terapi hemodialisis. Fakultas Psikologi US U. A vailable f r o m : http://www.library.usu.ac.id/download/fk/06010311.pdf [accesed 3 jan 2014]

6. Melti T,Arthur M, et al. Hubungan Antara Derajat Penyakit Ginjal Kronik Dengan Nilai Agregasi Trombosit Di RSUP Prof.Dr.R.D.Kandau Manado (Jurnal e-Biomedik (eBM), Volume 2, Nomor 2, Juli 2014

7. Suwitra K. Penyakit ginjal kronik. Dalam: Sudoyo Aru W, Setiyohadi Bambang, Alwi Idrus. Editors: Buku Ajar Ilmu Penyakit Dalam. Jilid II, Edisi V. Jakarta. Interna publishing;2009.h.1036 University Press,1997 